\title{
Edukasi dan Sosialisasi Pencegahan Virus Covid-19 Berawal Dari Diri Sendiri Di Desa Kampung Anyar Kecamatan Glagah Kabupaten Banyuwangi
}

\author{
${ }^{1}$ Feby Indriana Yusuf, ${ }^{2}$ Dzurotul Mutimmah, ${ }^{3}$ Novi Prayekti, \\ ${ }^{4}$ Reny Eka Evi Susanti, ${ }^{5}$ Fitri Nurmasari \\ ${ }^{1,2,3}$ Prodi Pend. Matematika, Univ. PGRI Banyuwangi, Jl. Ikan Tongkol 22, Banyuwangi, 68416 \\ ${ }^{4}$ Prodi Kimia, Universitas PGRI Banyuwangi, Jl. Ikan Tongkol 22, Banyuwangi, 68416 \\ ${ }^{5}$ Prodi Biologi, Universitas PGRI Banyuwangi, Jl. Ikan Tongkol 22, Banyuwangi, 68416
}

E-mail: feby.statistika@gmail.com

\begin{abstract}
Abstrak - Virus Corona menjadi salah satu virus yang telah menyebabkan SARS, MERS, dan Covid-19. Kabupaten Banyuwangi merupakan salah satu wilayah dengan grafik perkembangan Covid-19 yang menunjukkan peningkatan cukup tinggi. Berdasarkan data dari website corona.banyuwangikab.go.id pada bulan Agustus sebanyak 237 orang dinyatakan terinveksi Covid-19, pada bulan Desember terdata sebanyak 3963 oran. Hal tersebut menjadi perhatian utama banyak pihak khususnya pemerintah daerah dalam upaya untuk melakukan pencegahan penyebaran virus Covid-19. Kecamatan Glagah merupakan salah satu kecamatan yang terletak di bagian barat wilayah Banyuwangi. Desa Kampung Anyar merupakan salah satu desa di Kecamatan Glagah. Masyarakat di desa Kampung Anyar masih banyak yang belum mematuhi protokol kesehatan, sehingga kegiatan baik itu berupa sosialisasi melalui spanduk, melalui jejaring sosial dan melalui kegiatan masyarakat lainnya sangat diperlukan untuk dapat mensukseskan pemutusan mata rantai virus Covid-19. Selain sosialisasi terkait protokol kesehatan, edukasi kepada warga harus diberikan sehingga dalam melaksanakan protokol kesehatan dapat dilakukan sesuai aturan dan anjuran, supaya masyarakat melalui lingkup terkecil yaitu keluarga dapat saling menjaga dan melindungi agar tidak terinveksi virus Covid-19. Kegiatan ini meningkatkan kesadaran masyarakat desa Kampung Anyar bahwa mencegah sejak dini tidak serumit yang didengar melalui media sosial atau televisi, disamping itu ibuibu yang mengikuti kegiatan tersebut sepakat dan berkomitmen untuk menjadi garda terdepan di keluarganya dalam mencegah penyebaran Covid-19.
\end{abstract}

Kata Kunci - Sosialisasi, Edukasi, Pencegahan, Covid-19

\begin{abstract}
The Corona virus is one of the viruses that has caused SARS, MERS, and Covid-19. Banyuwangi Regency is one of the areas with a graph of the development of Covid-19 which shows a fairly high increase. Based on data from the corona.banyuwangikab.go.id website in August, 237 people were declared infected with Covid-19, in December there were 3963 people. This is the main concern of many parties, especially local governments, in an effort to prevent the spread of the Covid-19 virus. Glagah sub-district is one of the sub-districts located in the western part of the Banyuwangi region. Kampung Anyar Village is one of the villages in Glagah District. Many people in Kampung Anyar village still do not comply with health protocols, so that good activities in the form of socialization through banners, through social networks and through other community activities are needed to be able to successfully break the chain of the Covid-19 virus. In addition to socialization related to health protocols, education to residents must be provided so that in implementing health protocols it can be carried out according to rules and recommendations, so that the community, through the smallest scope, namely families, can protect and protect each other from being infected with the Covid-19 virus. This activity raises the awareness of the village community in Kampung Anyar that early prevention is not as complicated as heard through social media or television, besides that women who participate in these activities agree and are committed to being the front guard in their families in preventing the spread of Covid-19.
\end{abstract}

Keywords - Sosialization, Education, Prevention, Covid-19

\section{PENDAHULUAN}

Virus Corona menjadi salah satu virus yang telah menyebabkan SARS, MERS, dan Covid-19. Pemahaman yang tepat dengan usaha pencegahan sebaran virus menjadi upaya utama dalam mencegah penyebaran virus dengan tipe baru. Virus Corona dengan tipe baru yang penyebarannya begitu masif di berbagai belahan bumi ternyata terus bermutasi dari waktu ke waktu. Pola penyebaran virus Corona memiliki pola yang sangat luas dan berjalan dengan cepat, bahkan melebihi SARS atau MERS [1].

Wabah virus Corona ditetapkan sebagai daruratan kesehatan masyarakat yang meresahkan dunia atau PHEIC (Public Health Emergency Of 
International Concern). Beberapa hal mengenai virus Corona memang masih banyak yang belum diketahui, contohnya virus ini ditularkan melalui kontak langsung dengan percikan droplet dari saluran pernapasan orang yang terinfeksi. Tanda dan gejala dari penyakit ini diantaranya gangguan pernapasan akut, seperti demam, batuk dan sesak nafas. Pada kasus Covid-19 yang berat dapat menyebabkan pneumonia, sindrom pernapasan akut, gagal ginjal, hinggakematian. Masa inkubasi rata-rata 5-6 hari dengan masa inkubasi terpanjang yaitu 14 hari [2]. Masyarakat harus mengambil tindakan untuk mencegah penyebaran virus Corona ini. Selain itu, masyarakat juga harus mendukung mencegah penyebaran wabah dengan protokol kesehatan yang ditetapkan oleh pemerintah [3]. Pemerintah Indonesia telah menetapkan langkahlangkah dan upaya pencegahan pandemik Covid-19 salah satunya adalah dengan mensosialisasikan gerakan Social Distancing, konsep ini dapat mengurangi atau memutus mata rantai penularan atau penyebaran infeksi Covid-19, dalam upaya ini seseorang harus menjaga jarak dengan orang lain minimal 1-2 meter, dengan tidak melakukan kontak langsung dengan orang lain, dan menghindari kerumunan serta pertemuan masal [4].

Sejak bulan Agustus 2020 hingga Desember 2020 penyebaran virus Covid-19 di Indonesia semakin merajalela. Kabupaten Banyuwangi merupakan salah satu wilayah dengan grafik perkembangan Covid-19 yang menunjukkan peningkatan cukup tinggi. Berdasarkan data dari Kabupaten Banyuwangi, pada bulan Agustus sebanyak 237 orang dinyatakan terinveksi virus Covid-19 hingga pada bulan Desember terdata sebanyak 3963 orang. Hal tersebut menjadi perhatian utama banyak pihak khususnya pemerintah Kabupaten Banyuwangi dalam upaya untuk melakukan pencegahan dan penyebaran virus Covid-19 [5]. Kabupaten Banyuwangi memiliki 25 kecamatan yang tersebar baik di wilayah utara,selatan, timur dan barat. Pemerintah daerah secara kontinyu melakukan penertiban terkait protokol kesehatan melalui gugus Covid di masing-masing kecamatan. Kecamatan Glagah merupakan salah satu kecamatan yang terletak di bagian barat wilayah Banyuwangi. Desa Kampung Anyar merupakan salah satu desa di Kecamatan Glagah. Masyarakat di desa Kampung Anyar masih awam atau banyak yang belum mematuhi protokol kesehatan, sehingga kegiatan baik itu berupa sosialisasi melalui spanduk, melalui jejaring sosial dan melalui kegiatan masyarakat lainnya sangat diperlukan untuk dapat mensukseskan pemutusan mata rantai virus Covid-19. Selain sosialisasi terkait protokol kesehatan, edukasi kepada warga harus diberikan sehingga dalam melaksanakan protokol kesehatan dapat dilakukan sesuai aturan dan anjuran, supaya masyarakat melalui lingkup terkecil yaitu keluarga dapat saling menjaga dan melindungi agar tidak terinveksi virus Covid-19.

\section{METODE PELAKSANAAN KEGIATAN}

Kegiatan Edukasi Dan Sosialisasi Pencegahan Virus Covid-19 Berawal Dari Diri Sendiri dilaksanakan dengan tahapan sebagai berikut :

\section{Sosialisasi}

Sosialisasi dilaksanakan dengan menyajikan materi menggunakan media powerpoint dan video. Powerpoint berisi informasi perkembangan Covid-19 yang terjadi di Kabupaten Banyuwangi. Video berisi langkah mencuci tangan dengan baik dan benar serta cara menggunakan hand sanitizer yang baik dan benar.

\section{Edukasi}

Edukasi dilaksanakan dengan mempraktekan secara langsung melalui staterkit yang berisikan masker, hand sanitizer dan tisu. Tim pengabdian secara langsung mengajarkan kepada ibu-ibu peserta sosialisasi terkait cara menggunakan masker yang baik dan benar, jenis-jenis masker (medis/nonmedis, sekali pakai/masker kain), cara menggunakan hand sanitizer, cara mencuci tangan yang benar. Ibu-ibu peserta sosialisasi juga diberikan motivasi dan semangat untuk menjadi icon sebagai garda terdepan untuk menjaga kesehatan keluarga di rumah, sehingga ibu-ibu dihimbau untuk dapat meneruskan ilmu dan pemahaman yang didapat dari kegiatan pengabdian masyarakat ini

\section{HASIL DAN PEMBAHASAN}

Kegiatan Pengabdian kepada masyarakat dengan judul "Edukasi Dan Sosialisasi Pencegahan Virus Covid-19 Berawal Dari Diri Sendiri" dilaksanakan dengan memberikan materi kepada ibuibu terkait informasi terkait perkembangan virus Covid-19 di Kabupaten Banyuwangi melalui presentasi powerpoint seperti yang terlihat dari gambar 1 berikut :

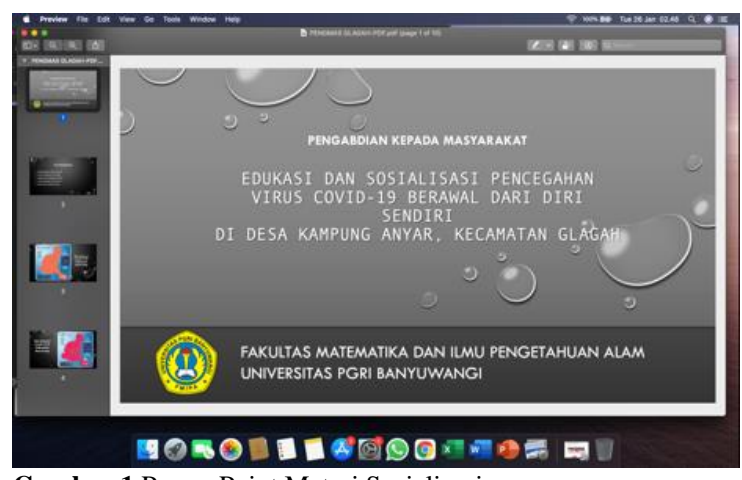

Gambar 1 Power Point Materi Sosialisasi

Selain menggunakan powerpoint ada beberapa video dan gambar sebagai media dalam menjelaskan ke masyarakat terkait pencegahan virus Covid-19 antara lain video cara mencuci tangan, menjaga jarak dan tujuannya, cara menggunakan hand sanitizer dan cara melakukan 5M sesuai anjuran pemerintah. 
Jati Emas (Jurnal Aplikasi Teknik dan Pengabdian Masyarakat) KESEHATAN \& KEDOKTERAN Vol. 5 No. 1 Maret 2021 - e. ISSN: 2550-0821

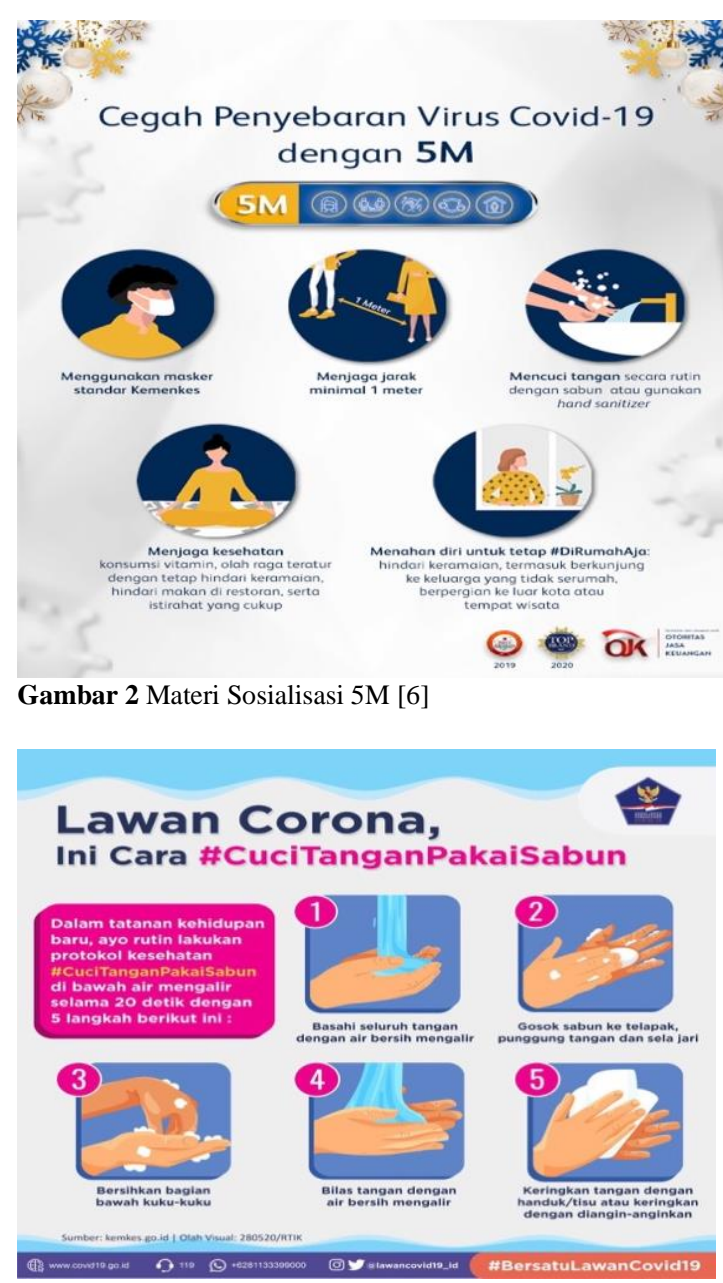

Gambar 3 Materi Sosialisasi Mencuci Tangan Pakai Sabun [7]

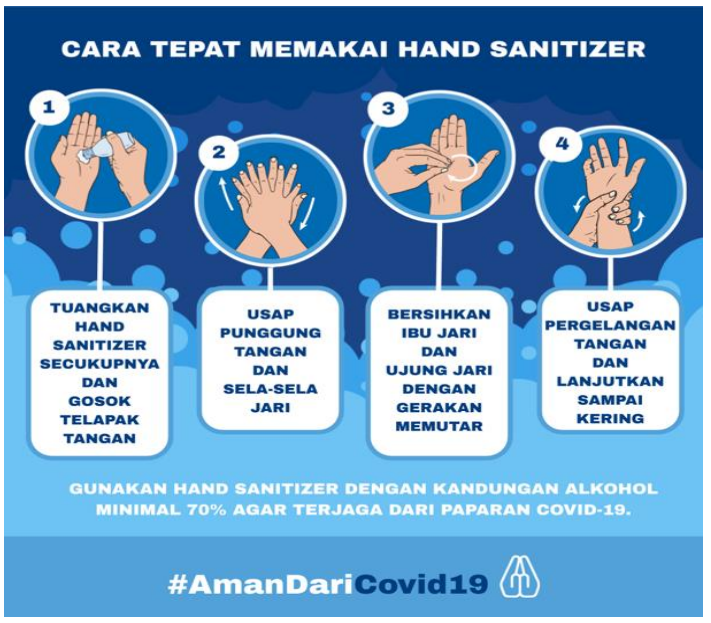

Gambar 4 Materi Sosialisasi Menggunakan Hand Sanitizer [8]

Sosialisasi dilakukan dengan komunikasi dua arah, dimana ibu-ibu juga dapat menanyakan secara langsung informasi-informasi yang ingin diketahui pencegahan penyebaran virus Covid-19. Setelah materi sosialisasi tersampaikan dan sesi tanya jawab usai, kegiatan selanjutnya adalah edukasi. Kegiatan pertama adalah mempraktikkan secara langsung tentang : a. Cara menggunakan, menyimpan dan membuang masker medis/non medis/masker sekali pakai.

b. Cara menggunakan masker bedah/surgical mask atau masker kain dengan sisi yang berwarna di sisi luar.

c. Memastikan bagian sisi masker yang terdapat kawat berada di sebelah atas.

d. Memposisikan masker menutupi seluruh bagian hidung, tarik hingga menutupi dagu.

e. Menekuk kawat di bagian atas masker hingga mengikuti lekuk tulang hidung.

f. Memastikan tidak ada celah antara masker dan wajah.

g. Menghindari menyentuh masker, terutama bagian luar, selama pemakaian. Jika tidak sengaja menyentuh masker, cuci tangan menggunakan sabun atau handrub.

h. Melepas dengan menarik tali belakang masker. Menghindari menyentuh bagian luar masker.

i. Mengganti masker setiap terkontaminasi atau terasa lembab. Segera membuang masker ke tempat sampah yang tertutup setelah masker dilepas. Tidak menggunakan masker berulang kali

j. Melakukan hand hygienel cuci tangan menggunakan sabun atau handrub setelah melepas masker [9].

Materi tersebut membuat ibu-ibu aktif dalam berinteraksi, dikarenakan masih banyak yang kurang benar dalam menggunakan maskernya, sehingga setelah praktik, mereka dapat memperbaiki cara menggunakan masker.

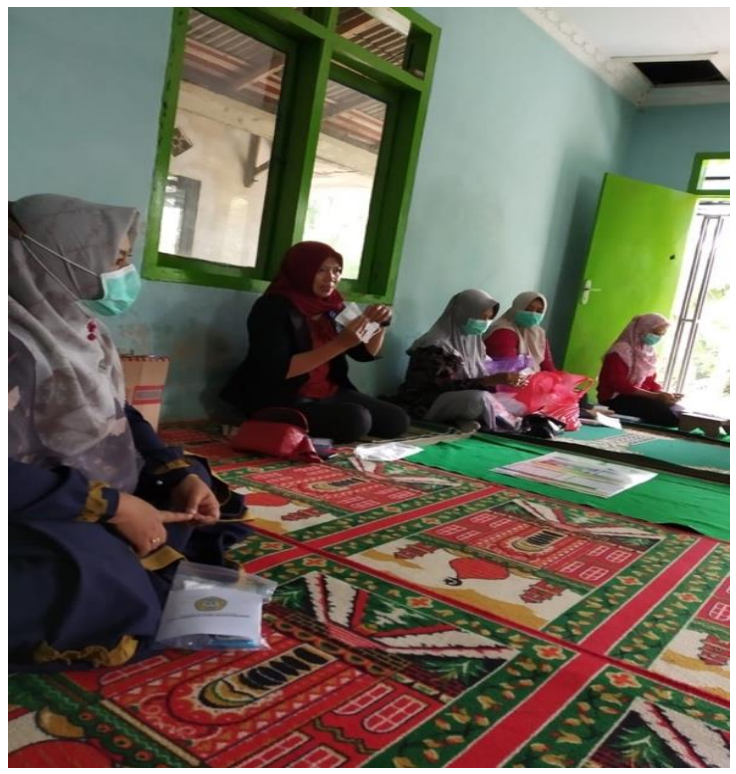

Gambar 5 Tim PkM menyampaikan cara menggunakan masker dengan baik dan benar 
Jati Emas (Jurnal Aplikasi Teknik dan Pengabdian Masyarakat) KESEHATAN \& KEDOKTERAN Vol. 5 No. 1 Maret 2021 - e. ISSN: 2550-0821

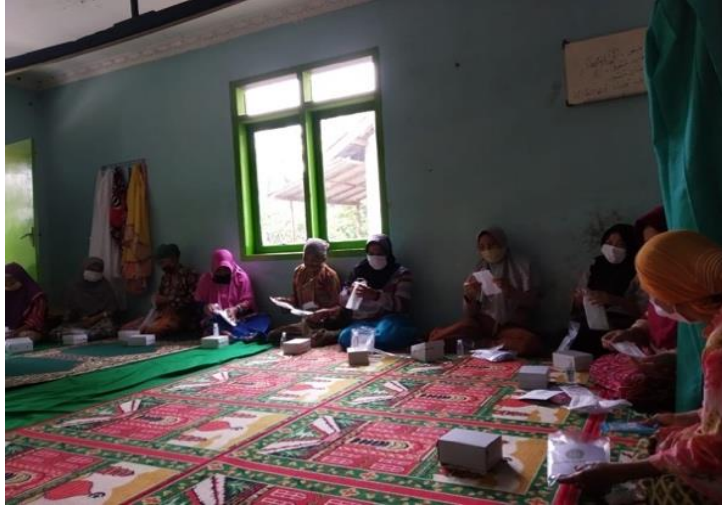

Gambar 6 Materi Edukasi - Praktik menggunakan masker medis (masker sekali pakai)

Kegiatan Edukasi yang kedua adalah cara yang baik dan benar dalam menggunakan hand sanitizer. Edukasi ini dilakukan karena pada dasarnya tangan menjadi salah satu agen yang membawa kuman pathogen berpindah dari satu orang ke orang lain [10]. Ibu-ibu sangat antusias dan aktif bertanya terkait penggunaan hand sanitizer. Banyak peserta yang belum menyadari pentingnya selalu membawa hand sanitizer saat keluar rumah. Setelah sosialisasi dan edukasi, ibu-ibu peserta pengabdian masyarakat berkomitmen untuk membawa hand sanitizer saat keluar rumah atau bepergian khususnya jika bepergian ke tempat yang tidak ditemukan tempat cuci tangan.

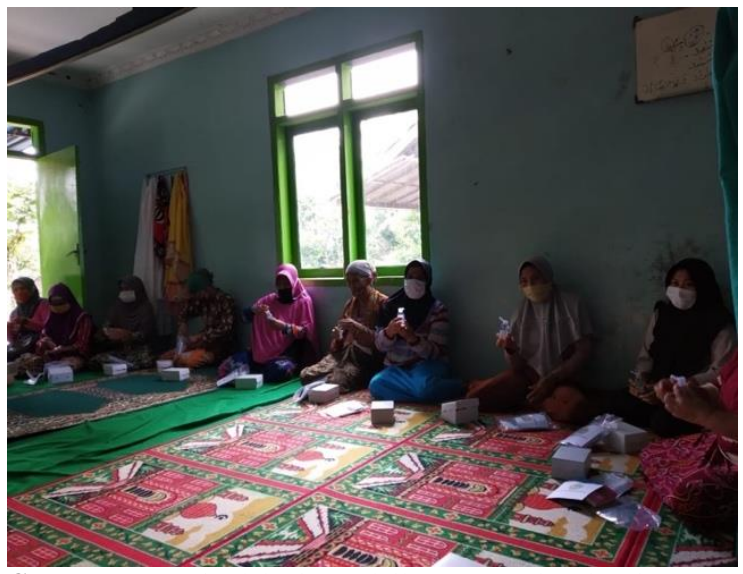

Gambar 7 Materi Edukasi - Praktik menggunakan hand sanitizer

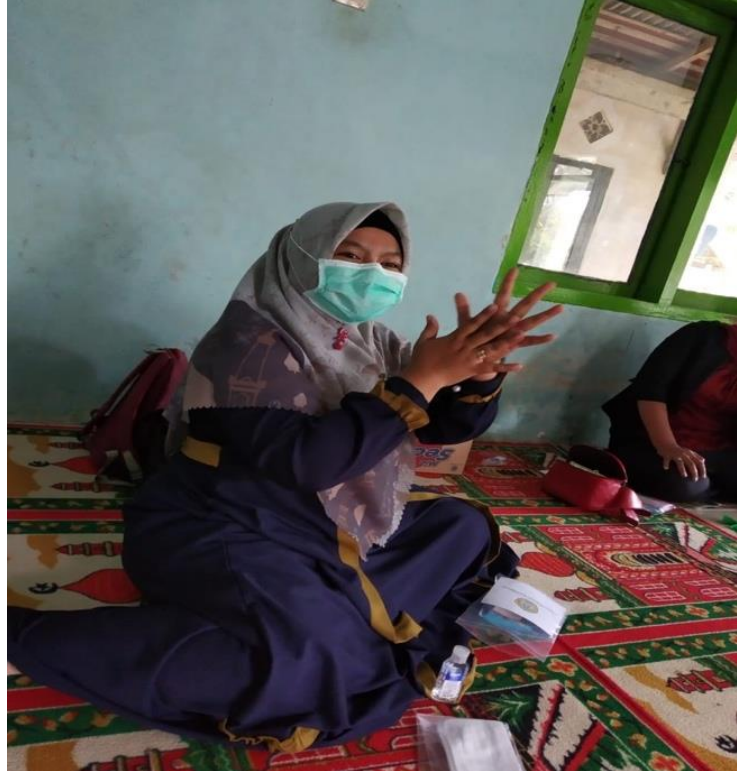

Gambar 8 Tim PkM mempraktikkan cara menggunakan hand sanitizer

Kegiatan terakhir adalah motivasi kepada ibu-ibu bahwa ibu-ibu berperan sebagai icon dan gugus terdepan di rumah untuk menjaga kesehatan dan kebersihan selalu guna mencegah dari berbagai penyakit. Ibu-ibu sangat antusias dan aktif bertanya tentang cara menjaga imunitas yang sederhana, cara mengingatkan keluarga yang tidak mau memakai masker saat keluar rumah dan lain hal terkait pencegahan virus Covid-19.

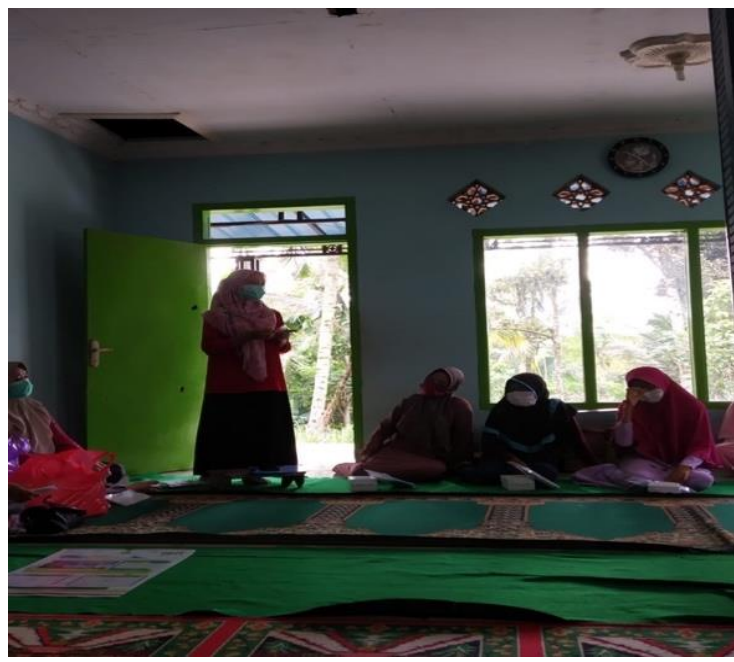

Gambar 9 Sesi tanya jawab 


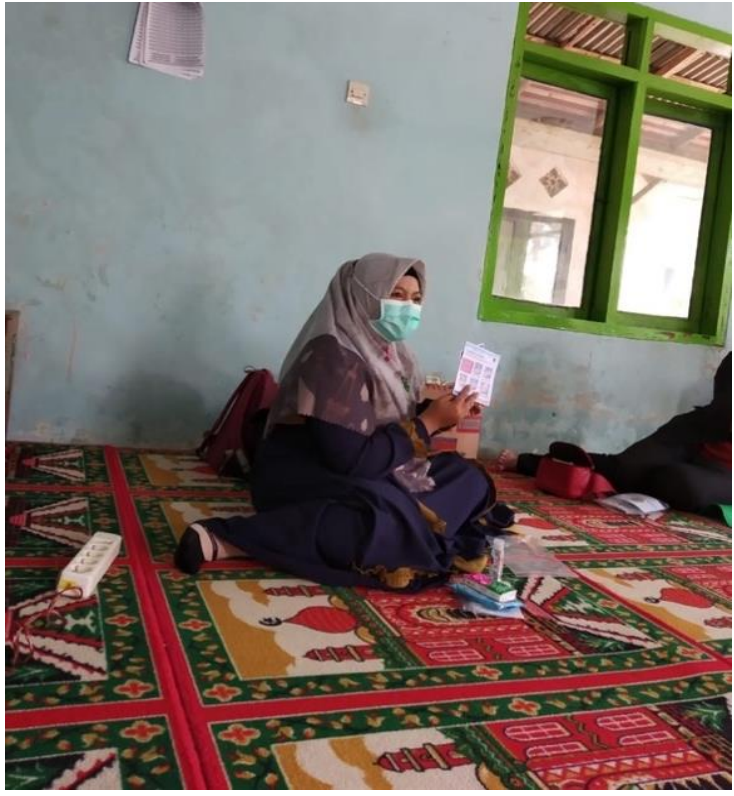

Gambar 10 Membekali ibu-ibu dengan staterkit pencegahan Covid-19

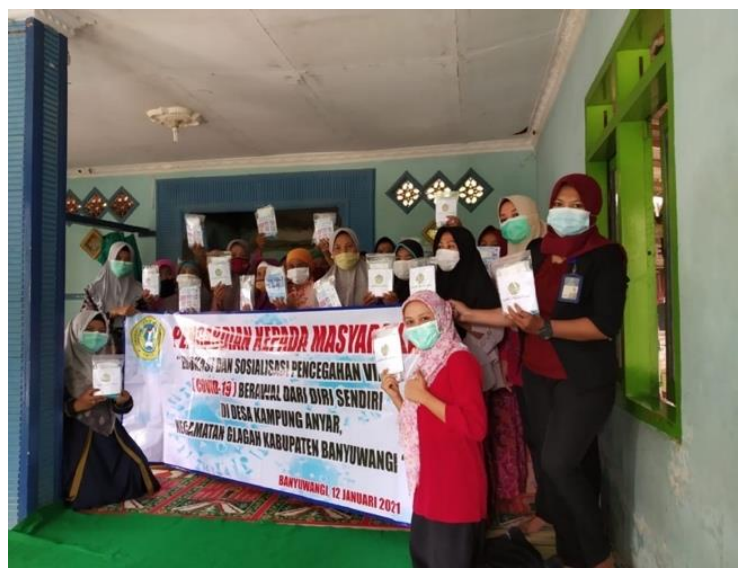

Gambar 11 Foto bersama-sama Ibu-Ibu RT 02 RW 02 Desa Kampung Anyar

\section{KESIMPULAN}

Kegaiatan sosialisasi dan edukasi tentang pencegahan virus Covid-19 di RT 02 RW 02 Dusun Kompen Cungking Desa Kampung Anyar memberikan dampak tentang memahami bahwa cara melakukan pencegahan virus Covid-19 sangat sederhana, yaitu dengan menerapkan program $5 \mathrm{M}$ (menggunakan masker, mencuci tangan /menggunakan hand sanitizer, menjaga jarak, menjaga kesehatan dan mengurangi bepergian keluar rumah). Ibu-ibu paham dan dapat mempraktikkan cara menggunakan hand sanitizer dan masker dengan baik dan benar. Disamping itu ibu-ibu berkomitmen bersama-sama untuk menjadi gugus terdepan di rumah masing-masing dalam mencegah penyebaran virus Covid-19.

\section{DAFTAR PUSTAKA}

[1] Yanti, Etri, Nova Fridalni, dan Harmawati. 2020. Mencegah Penularan Virus Corona. Jurnal Abdimas Saintika Vol. 2 No.1, 33-39.

[2] Kurniati, N., dkk. 2021. Edukasi Pencegahan Penyebaran Corona Virus Disease (Covid-19) Pada Masa Tatanan Baru (New Normal) Di Ruang Terbuka Hijau Pagutan Kota Mataram. E-Amal Jurnal Pengabdian Kepada Masyarakat Vol.1, No. 1,14

[3] Ausrianti, R., Andayani, R. P., Surya, D. O., \& Suryani, U. 2020. Edukasi Pencegahan Penularan Covid 19 serta Dukungan Kesehatan Jiwa dan Psikososial pada Pengemudi Ojek Online. Jurnal Peduli Masyarakat Vol.2 No.2, 59-64.

[4] World Health Organization. (2020). Novel coronavirus (2019-nCoV). Situation report, 28.

[5] Website Resmi Informasi Penyebaran Corona Virus di Kabupaten Banyuwangi. Link : https://corona.banyuwangikab.go.id/\#petasebaran

[6] Website BAF. Link :

https://www.baf.id/website/assets/Slider/73d369a b48b6b7cf149f564951409d52.jpeg

[7] Website Resmi Pemerintah terkait Informasi Covid-19. Link :

https://www.baf.id/website/assets/Slider/73d369a b48b6b7cf149f564951409d52.jpeg

[8] Website Aman dari Covid-19. Link : https://www.amandariCovid19.com/post/caratepat-memakai-hand-sanitizer-1

[9] Siregar, R., Adventy Riang Bevy Gulo, Lasma Rina Efrina Sinura. 2020. Edukasi Tentang Upaya Pencegahan Covid-19 Padamasyarakat Di Pasar Sukaramaikecamatan Medan Area Tahun 2020. Jurnal Abdimas Mutiara Vol.1 No.2, 197.

[10] Saida. 2020. Cegah Covid 19 melalui Edukasi Perilaku Hidup Bersih Dan Sehat Di Kecamatan Puwatu Kota Kendari. Journal Of Community Engagement in Health Vol.3 No.2, 330. 
Jati Emas (Jurnal Aplikasi Teknik dan Pengabdian Masyarakat) KESEHATAN \& KEDOKTERAN Vol. 5 No. 1 Maret 2021 - e. ISSN: 2550-0821 